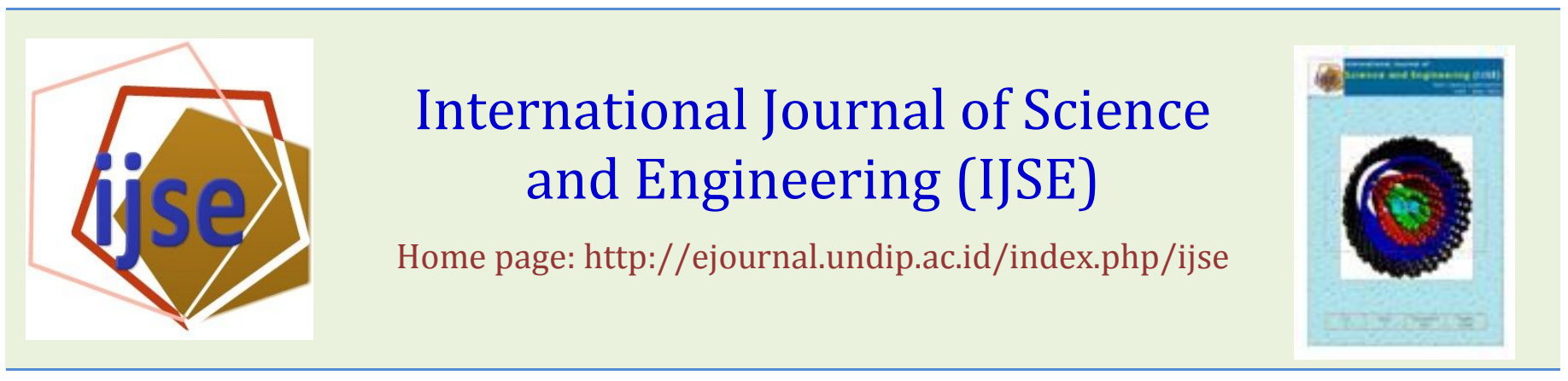

\title{
A Study of Local Rice Cultivars from Krayan Grown in Tidal Swam Area
}

\author{
Rusdiansyah $^{1)}$ and Tjatjuk Subiono ${ }^{1)}$ \\ 1)Departaement of Agrotectology, Faculty of Agriculture Mulawarman University, Jl. Pasir Belengkong Kampus Gung Kelua Samarinda,
} 75123, Telp. (0541)749313, Fax.(0541) 749313

Email: rrida_rusdi@yahoo.co.id

\begin{abstract}
The research was conducted in tidal swamp area of Tuak river, Paser Regency. The objective of the research was to obtain rice cultivar with high adaptability and yield grown in tidal swamp area. The study used four local rice cultivars of Krayan i.e. Nanung, Kelabit, Black Adan and White Adan. As a comparison, Yellow Serai was used. The rice was seeded in $5 \times 7 \mathrm{~m}$ plot with a planting distance of $30 \times 30 \mathrm{~cm}$ and 1 seed per planting hole. The treatment was replicated three times in a randomized block design. The result showed that all the four cultivars of Krayan had higher height than Yellow Serai. Nanung was found to be the most tolerant cultivar to salinity and the most adaptable in tidal swamp area. Nanung also produced the highest number of rough rice, the highest yield of weight per 1000 grains, the highest yield of weight of milled rice/ha and the least percentage of empty rough rice/panicle i.e. 182 grains, 29.35 $g, 4.20$ t/ha, and $15 \%$, respectively.
\end{abstract}

Keywords-study; local rice; tidal swamp area

Submission: February 20, 2014

Correction: April 2, 2014

Accepted: April 15, 2014

Doi: $10.12777 /$ ijse.6.2.131-134

[How to cite this article: Rusdiansyah and Tjatjuk Subiono. (2014). A Study of Local Rice Cultivars from Krayan Grown in Tidal Swam Area, International Journal of Science and Engineering, 6(2),131-134. Doi: 10.12777/ijse.6.2.131-134

\section{INTRODUCTION}

The major constrains limiting the rice production in tidal swamp area in East Kalimantan is due to environment factors such as pest and disease attack, high acidity level and $\mathrm{Al}, \mathrm{Fe}$, and $\mathrm{H}_{2} \mathrm{~S}$ toxicity (Sarwani et al., 1994). High level of acidity influences the chemical reaction process and the availability of soil nutrient. Al toxicity occurs at dry soil accompanied by scarcity of $\mathrm{P}$ content. Fe toxicity occurs at soil inundation which can diminish the yield of susceptible rice up to $70 \%$ (Virmani, 1977; Ismunadji, 1990).

Other toxic problem i.e. $\mathrm{Fe}$ and $\mathrm{H}_{2} \mathrm{~S}$ can also diminish the yield (Makarim et al., 1989). Another condition showing that $\mathrm{Na}$ toxicity occurs due to sea wave intrusion (Aswidinnoor et al., 2008) where high level of $\mathrm{Na}^{+}$can diminish the amount of exchangeable $\mathrm{Ca}^{2+}, \mathrm{Mg}^{2+}$ and $\mathrm{K}^{+}$(Suwarno and Salehuddin, 1983). The content of macro nutrient such as $P$ and $K$ and also micro nutrient including $\mathrm{Zn}, \mathrm{Cu}$ and $\mathrm{Bo}$ is low and not available for plants (Widjaja-Adhi and Alihamsyah, 1998; Suhartini, 2001).

In order to overcome the problems emerged in tidal swamp area is to utilize the local rice cultivar. East Kalimantan with specific climate has abundant cultivars of rice and adaptable to various specific environmental condition. Among of those, some of cultivars are grown at latitude higher than $900 \mathrm{~m}$ above sea level and has not been optimally utilized (Rusdiansyah, 2003). Those local rice cultivars are considered as a valuable asset and presents diversity in rice breeding program or as an alternative to increase the production of rice with heavy environmental constraint. According to Ifansyah and Priatmadi (2003), local rice cultivar is confirmed to have natural resistance toward pest and disease and rigidity towards toxicity of pyrit, $\mathrm{H}_{2} \mathrm{~S}, \mathrm{Na}$ and so on.

According to the problems mentioned above, this research was designed to test or study the local rice cultivar of Krayan grown tidal swamp area. The objective of this research was to obtain the local rice cultivars of Krayan which has high growth and yield grown tidal swamp area.

\section{MATERIAL AND METHOD}

The test was carried out during dry season in tidal swamp area in Sungai Tuak village, Tanah Gerogot sub district, Paser regency. Four local rice cultivars from Krayan upland were examined i.e. Nanung, Kelabit, Black Adan and White Adan. Another cultivar which commonly used by local farmer i.e. Yellow Serai was also grown for comparison. Other supporting materials including Urea fertilizer, SP-36 and $\mathrm{KCl}$, insecticide and fungicide were used in this research.

Statistical design used was randomized block design with three replications. The obtained data was subjected to analysis of variance at $5 \%$ significance level and followed by Least Significance Difference (LSD) at $5 \%$ if demonstrate 
significance difference. Five cultivar materials were denoted as follows: $\mathrm{k}_{1}=$ Nanung; $\mathrm{k}_{2}=$ Kelabit; $\mathrm{k}_{3}=$ Black Adan; $\mathrm{k}_{4}=$ White Adan and as a comparison $\mathrm{k}_{5}=$ Yellow Serai.

The seeds were grown in seedbed with $2 \times 3 \mathrm{~m}$ size. Twenty old seedlings were transplanted in $5 \times 7 \mathrm{~m}$ plots at a spacing of $30 \times 30 \mathrm{~cm}$ with 1 seed per planting hole. Fertilizer such as Urea, SP36, and KCL was applied for N, P and K source with a dosage of $75 \mathrm{~kg} \mathrm{~N} / \mathrm{ha}, 45 \mathrm{~kg} \mathrm{P}_{2} \mathrm{O}_{5} / \mathrm{ha}$ and $45 \mathrm{~kg}$ $\mathrm{K}_{2} \mathrm{O} / \mathrm{ha}$, respectively. The observed parameters were height of plant, number of tiller/clump, number of productive tiller/clump, number of rough rice and percentage of empty rough rice, weight of 1000 grains and milled rice/ha.

\section{RESULT AND DISCUSSION}

According to the statistical analysis result, it was found that significant difference occurred among treatment materials. The result of LSD at 5\% showed that all treated materials had higher height and significantly different to the comparison material namely Yellow Serai. The highest was Black Adan with $173 \mathrm{~cm}$ height and the shortest was Yellow Serai with $139 \mathrm{~cm}$ height (Table 1, Fig. 1). All local cultivars had been provided from area higher than $900 \mathrm{~m}$ above sea level with temperature ranges from 19 to $25^{\circ} \mathrm{C}$ (Rusdiansyah, 2003). However, the condition affects the adaptation of the treated materials which planted in the study site with less than $100 \mathrm{~m}$ above sea level and the temperature ranges from 27 to $33^{\circ} \mathrm{C}$. High temperature caused faster cell division and elongation which triggered longer stem growth that generated higher height at local rice cultivar.

According to the LSD at 5\% showed that all rice cultivars of Krayan produced fewer number of tillers and significantly different to Yellow Serai cultivar. In case of productive tillers/clump, besides of Nanung cultivar, the other three cultivars of Krayan produced fewer number and significantly different to Yellow Serai cultivar. Yellow Serai produced the highest number of tillers/clump and productive tillers/clump i.e. 15 and 16 tillers, respectively. The fewest one was Black Adan with 18 and 7 tillers, accordingly (Table 1; Fig. 2). The height of plant affected the generation of tillers. This related to the length and position of stem segment to the soil surface. The possibility of tillers generation decreased along the higher of stem segment from the soil surface. Besides, sea water intrusion (salinity) that have occurred from 41 days old plant up to flowering phase also affected the few number of tillers. Visual observation indicated that salinity caused drought and mortality of the tillers. In addition, the leaves also got smaller and experienced chlorosis due to nutrient deficiency.

Table 1. Height, number of tillers/clump and number of productive tillers/clump of local rice cultivars from Krayan and Yellow Serai

\begin{tabular}{|l|c|c|c|}
\hline \multicolumn{1}{|c|}{ Cultivar } & Plant height $(\mathrm{cm})$ & Number of tillers/clump (culm) & Number of productive tillers/clump (culm) \\
\hline Nanung & $170^{\mathrm{ab}}$ & $20^{\mathrm{b}}$ & $15^{\mathrm{ab}}$ \\
\hline Kelabit & $155^{\mathrm{bc}}$ & $21^{\mathrm{ab}}$ & $7^{\mathrm{d}}$ \\
\hline Black Adan & $173^{\mathrm{a}}$ & $18^{\mathrm{b}}$ & $10^{\mathrm{cd}}$ \\
\hline White Adan & $168^{\mathrm{ab}}$ & $21^{\mathrm{ab}}$ & $16^{\mathrm{a}}$ \\
\hline Yellow Serai & $139^{\mathrm{c}}$ & $25^{\mathrm{a}}$ & \\
\hline
\end{tabular}

Note: means with the same letter at the same column is not significantly different at LSD 5\%

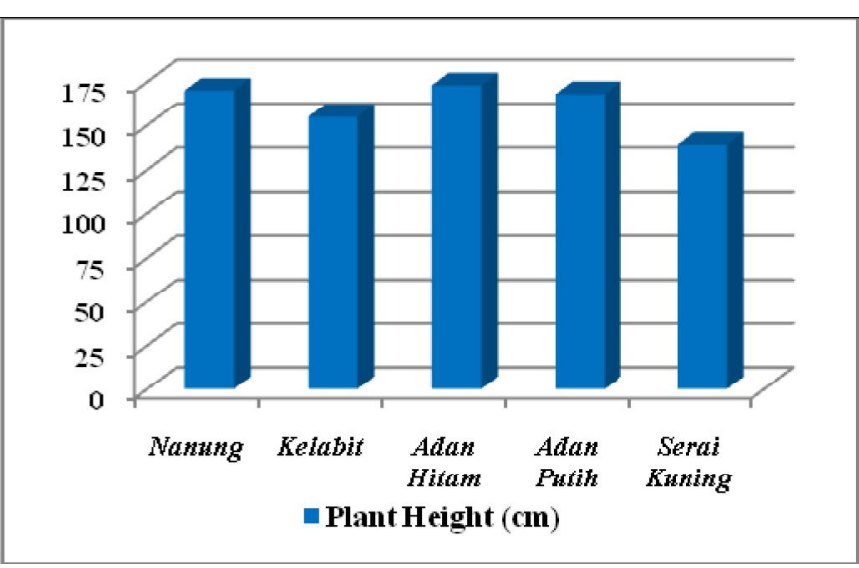

Figure 1. The plant height of four cultivars of Krayan and Yellow Serai

The increases of $\mathrm{Na}^{+}$content in soil due to sea water intrusion inhibits the root growth and decreases number of tillers (Rahmawati, 2006) and decreases biomass (Sipayung, 2006). According to Suwarno and Salehuddin (1983), Suwarno (1985), increasing of $\mathrm{Na}^{+}$content leads to decreasing of exchangeable $\mathrm{Ca}^{2+}, \mathrm{Mg}^{2+}$ and $\mathrm{K}^{+}$which reduces the nutrient availability. According to Sari et al., (2006), increasing of $\mathrm{Na}^{+}$in the soil causes deficiency of $\mathrm{Ca}^{+}$content that affects the growth of root. Besides, salinity will increase $\mathrm{Cl}^{-}$concentration in the soil and replaces $\mathrm{K}^{+}$which used to transport the nutrient that leads to impede the absorption of $\mathrm{NO}_{3}{ }^{-}$.

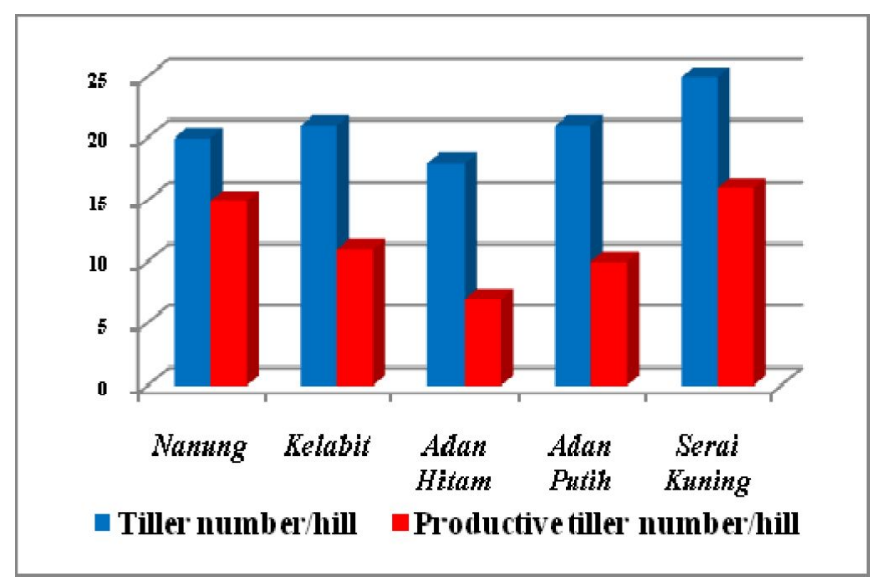

Figure 2. Number of tillers/clump and productive tillers/clump of 4 cultivars of Krayan and Yellow Serai 
Among five materials used in this research, Nanung produced the highest yield in terms of total grain/panicle, total weight per 1000 grains, and total weight of milled rice/ha i.e. 182 grains, $29.35 \mathrm{~g}$ and $4.10 \mathrm{t} / \mathrm{ha}$, respectively. In contrast, Nanung produced the least percentage of empty rough rice/panicle i.e. $15 \%$. Meanwhile, the highest percentage of empty rough rice/panicle, the lightest weight of grain per 1000 grains and the fewest number of rough rice/panicle were resulted by Kelabit cultivar i.e. 40\%, 19,50 g, and 141 grains, respectively. The lightest weight of milled rice was resulted by Black Adan cultivar i.e. 1.09 t/ha. The result of LSD at 5\% significance level showed that Nanung cultivar was not significantly different with Black Adan and Yellow Serai but showed significant different with Kelabit and White Adan in term of total grain/panicle. However, Nanung cultivar was significantly different with Yellow Serai and three others cultivars in term of total weight per 1000 grains and total weight of milled rice (Table 2, Fig. 3 and 4).

Table 2. Total number of rough rice/panicle, percentage of empty rough rice/panicle, total weight of 1000 grains and total weight of milled rice/ha of 4 cultivars of Krayan and Yellow Serai cultivar

\begin{tabular}{|l|c|c|c|c|}
\hline \multicolumn{1}{|c|}{ Cultivar } & $\begin{array}{c}\text { Total number of rough } \\
\text { rice/panicle (grain) }\end{array}$ & $\begin{array}{c}\text { Percentage of empty rough } \\
\text { rice/panicle (\%) }\end{array}$ & $\begin{array}{c}\text { Total weight of } \\
1000 \text { grains (g) }\end{array}$ & $\begin{array}{c}\text { Total weight of milled } \\
\text { rice (t/ha) }\end{array}$ \\
\hline Nanung & $182^{\mathrm{a}}$ & $15^{\mathrm{a}}$ & $29.35^{\mathrm{a}}$ & $4.20^{\mathrm{a}}$ \\
\hline Kelabit & $141^{\mathrm{b}}$ & $40^{\mathrm{c}}$ & $19.50^{\mathrm{c}}$ & $1.57^{\mathrm{c}}$ \\
\hline Black Adan & $180^{\mathrm{a}}$ & $27^{\mathrm{b}}$ & $23.87^{\mathrm{b}}$ & $1.09^{\mathrm{c}}$ \\
\hline White Adan & $147^{\mathrm{b}}$ & $39^{\mathrm{c}}$ & $23.41^{\mathrm{bc}}$ & $1.73^{\mathrm{c}}$ \\
\hline Yellow Serai & $172^{\mathrm{ab}}$ & $32^{\mathrm{b}}$ & $25.66^{\mathrm{b}}$ & $2.80^{\mathrm{b}}$ \\
\hline
\end{tabular}

Note : means with similar letter does not show significant different at $5 \%$ of LSD

According to the result mentioned previously, the total yield of rough rice/panicle of each cultivar was affected by their genetic factor. However, different characteristic had been occurred at the result of percentage of empty rough rice/panicle, total weight of 1000 grains and total weight of milled rice/ha which was strongly depend on the salinity level.

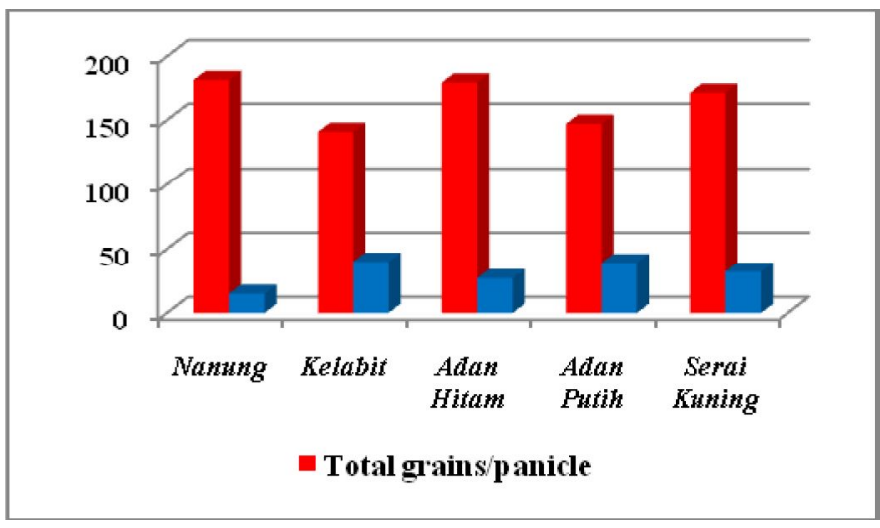

Figure 3. Total number of rough rice/panicle and percentage of empty rough rice/panicle of four cultivars from Krayan and Yellow Serai

The adaptability of rice to salinity is strongly influenced by the ability to adjust their turgor pressure. A rigid rice plant will fasten their activity on balancing the ion concentration inside the cell so that the root elongation and lateral root formation can take place and the nutrient uptake is back to normal. In a susceptible rice plant, salinity will damage the root so that the nutrient accumulates in the root zone but cannot be absorbed by the plant due to abnormal root growth.

Inhibition of nutrient uptake will affect the generative growth of rice plant. The panicles are empty or incompletely filled and form into small size that reduces the weight of the yield. According to Sunarto (2001), in case of soybean, salinity affects the formation of grain inside the pod that reduces the weight of the grain. While in rice plant,
Rahmawati (2006) stated that salinity decreases the number of the rice grain, decreases the weight of 1000 rough rice grains and dry weight of plant. Moreover, Sembiring and Gani (2006) mentioned that salinity can decrease rough rice yield up to $50 \%$.

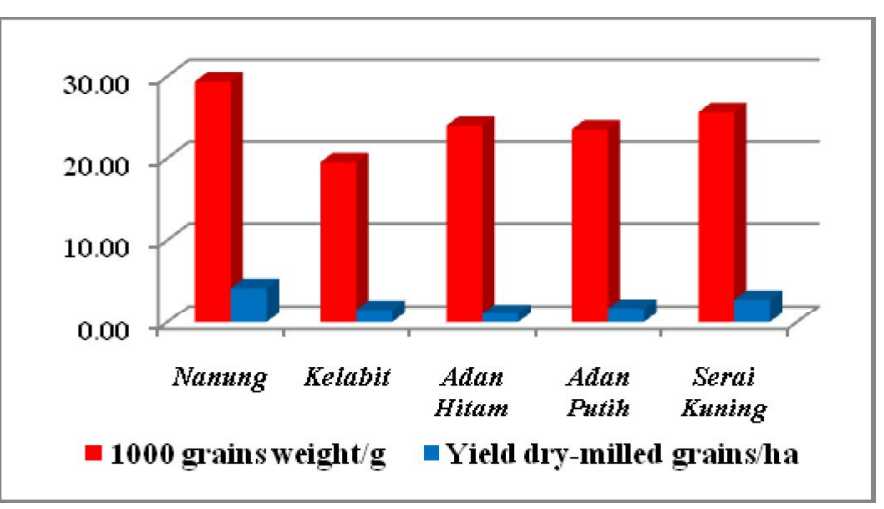

Figure 4. Total weight of 1000 grains and total weight of milled rice/ha of four cultivars from Krayan and Yellow Serai

According to the overall test result, it was found that Nanung cultivar was more tolerant to salinity and had better adaptability in tidal swamp area in Sungai Tuak village. This suggests that Nanung cultivar is recommended to be grown and to be tested in others environment condition.

\section{CONCLUSION}

All local rice cultivars from Krayan had higher height and fewer number of tillers/clump as compared to Yellow Serai cultivar. In tidal swamp area, Nanung cultivar was more tolerant to salinity and had better adaptability compared to other cultivars. Nanung cultivar also produced the highest number of rough rice/panicle, least percentage of empty rough rice/panicle, highest yield of weight per 1000 grains and highest yield of weight of milled rice/ha i.e. 182 grains, $15 \%, 29.35 \mathrm{~g}$ and $4.20 \mathrm{t} / \mathrm{ha}$, respectively. 


\section{REFERENCES}

[1]. Aswidinnoor,H.,M. Sabran, Masganti and Susilawati, 2008 Development of new cultivar of high yielding rice and ratoon grown in tidal swamp area in Kalimantan to support two times harvesting a year. LPPM, IPB Bogor. $30 \mathrm{~h}$.

[2]. Ifansyah, H. and B.J. Priatmadi. 2003. Nitrogen availability in tidal swamp area planted by local rice without fertilization. J. Tanah Tropika (16): 87-96.

[3]. Ismunadji, M. 1990. Alleviating iron toxicity in lowland rice. Indonesian Agric. Res. And Development J. 12 (4): 67-72.

[4]. Makarim, K., O. Sudarman and H. Supriadi. 1989. Nutrient status of rice plant in the area affected Fe toxic in Batumara, South Sumatera. Penelitian Pertanian 9 (4): 166-170.

[5]. Rahmawati, 2006. Status of genetic development and improvement of rice using Agrobacterium transformation technique. Agrobiogen 2: 364-375.

[6]. Rusdiansyah, 2003. In-situ exploration and identification of the diversity of local rice cultivar in Krayan sub district, Nunukan district, East Kalimantan. Faculty of Agriculture, University of Mulawarman (unpublished).

[7]. Sari, H. C., S. Darmanti and E. D. Hastuti. 2006. The growth of "emprit" ginger (Zingiber officinale var. Rubrun) planted at sandy medium with different salinity level. Bul. Anatomi dan Fisiologi 14 (2): 19-29.
[8]. Sarwani, M., M. Noer and Masganti. Potency, constraint, and opportunity of tidal swamp area in the perspective of food crop development. In Water management and productivity of tidal swamp area. Office of Food Crop Research, Banjarbaru.

[9]. Sembiring, H. and A. Gani. 2006. Adaptability of rice on tsunami affected soil. http://www.dpi.nsw.gov.au/data/assets/pdf_file/0009/ 199449/Adaptability-of-rice-on-tsunami-affected-soil.pdf.

[10]. Sipayung, R. 2006. Salt stress and tolerant mechanism of a plant. Hayati (5): 18-20.

[11]. Suhartini, T. 2001. The role of rice cultivar diversity in increasing productivity of area affected Fe toxicity. Bul. Agron. 29 (2): 35-39.

[12]. Sunarto. 2001. Soybean tolerance to salinity. Bul. Agron. 29 (1): 27-30

[13]. Suwarno and S. Solahuddin. 1983. Cultivar tolerance of rice to salinity during germination stage. Bul. Agron. 14 (3): 1-15.

[14]. Suwarno, 1985. Inheritance and physiology of salinity tolerance characteristic in rice plant. Dissertation of Graduate School, IPB, Bogor. $87 \mathrm{~h}$.

[15]. Virmani, S.S. 1977. Varietal tolerance of rice to Iron toxicity in Liberia. Intern. Rice Res. Newsl. 2 (1): 4-5.

[16]. Widjaja-Adhi, I.P.G. and T. Alihamsyah. 1998. The development of tidal swamp area: potency, opportunity, constrain and technology for agriculture. In the Seminar Proceeding of Soil Science, East Java. 